\title{
CAPITAL ADEQUACY RATIO TESTING IN THE PERFORMANCE OF REGIONAL DEVELOPMENT BANKS (BPD) IN EASTERN INDONESIA
}

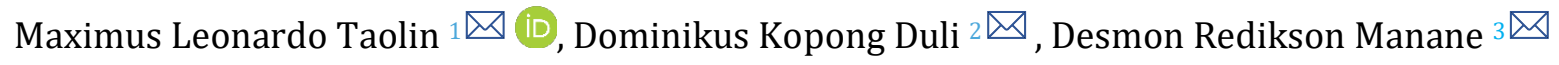 \\ 1, 2, 3 Faculty of Economic and Business, University of Timor, Indonesia
}

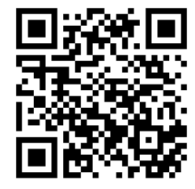

Received 16 December 2021

Accepted 29 January 2022

Published 18 February 2022

\section{CorrespondingAuthor}

Maximus Leonardo Taolin, maxtaolin@yahoo.com

DOI 10.29121/ijetmr.v9.i2.2022.1106

Funding: This research received no specific grant from any funding agency in the public, commercial, or not-for-profit sectors.

Copyright: (C) 2022 The Author(s). This is an open access article distributed under the terms of the Creative Commons Attribution License, which permits unrestricted use, distribution, and reproduction in any medium, provided the original author and source are credited.

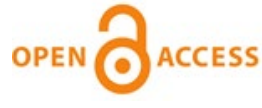

\section{ABSTRACT}

This study aims to examine the empirical models of BOPO, NPL, LDR and ROE mediated by CAR, using PLS linear regression with the inner model of the warp3 algorithm, which tries to identify the relationship between latent variables that follow the $S$ curve. The results show the path coefficients and $p$-values for each direct effect between variables that influence positive. The relationship the BOPO and ROE shows a significant at 0.002 , the relationship the NPL and ROE shows a coefficient value, 0.182 which is significant at $0.046^{*}$, the LDR relationship to ROE shows a coefficient value, 0.048 which is not significant at 0.276 . The relationship BOPO and CAR shows a coefficient, 0.277 which is significant at $0.001^{* * *}$, the relationship between NPL and CAR shows a coefficient, 0.289 which is significant at $0.009^{* * *}$, the relationship between LDR and CAR variables shows a coefficient, 0.135 which is not significant at 0.232 . Meanwhile, the relationship between the CAR and ROE shows a coefficient of 0.237 , which is significant at $0.015^{* *}$.

The results of the mediating effect of the indirect effect coefficient BOPO $\rightarrow \mathrm{CAR} \rightarrow \mathrm{ROE}$ is 0.066 with a $p$-value of $0.038(\mathrm{p}<5 \%)^{*}$. explained that CAR is able to mediate the effect of BOPO on ROE.

Keywords: 9 BPD (Indonesian Regional Development Banks), BOPO (Operational Efficiency Ratio) NPL, LDR, ROE, and CAR

\section{INTRODUCTION}

The COVID-19 pandemic has caused the economy to become sluggish. The situation in the banking sector affects all parties without exception. The banking sector is closely related to the macroeconomic system, government monetary policy, fiscal policy, government system, legal, political, social, and so on. Which if you don't implement a control strategy, you will also be swept away in a crisis of confidence as a result of the Covid 19 Pandemic.

The Covid-19 pandemic has caused banks to also experience a contraction in their financial performance. Banking performance is highly dependent on its market share in groups of business actors Sudana (2015). If this pandemic continues for a long time, it will be very worrying for the economic condition of the area where the Bank is located, making the eastern region its niche market.

In terms of Performance and Banking Conditions when compared to the situation during the 1997-1998 Monetary Crisis and the pandemic. According to economic experts, Indonesian banking conditions in the midst of the pandemic are still considered stable and healthy when compared to the 
economic crisis that occurred in 1997-1998. This comparison is very clear when comparing the ratio of non-performing loans (NPL) for each period. Research Director of the Center of Reform on Economics (Core) Indonesia Piter Abdullah said, in the midst of the pandemic, the ratio of non-performing loans or non-performing loans (NPL) of the Indonesian banking industry was still below 5 percent. which reaches 50 percent.

This comparison can be proven by the BPD (Indonesian regional development banks) financial performance report, until December 2020, where the BPD experienced an increase, even when the national banking sector experienced a decline, but on the other hand BPD (Indonesian regional development banks) experienced a 5.15\% growth in credit distribution, while the national banking sector fell by $2.41 \%$. (Report of the chairman of Asbanda) In fact, when some banks provided financial reports that were in difficult conditions, a number of BPDs even posted positive financial reports.

In the January 2020 period, Indonesia's capital adequacy ratio (CAR) was $22.83 \%$. This figure decreased in the same period in 2019 which was $23.4 \%$. Furthermore, in March 2020, the CAR position was 21.67\%. continued as of June 2020 the position of the Capital Adequacy Ratio (CAR) was at the level of $22.59 \%$. In this position, it seems that bank capital in the country is still very strong where the capital adequacy ratio (CAR) continues to increase during the Covid-19 pandemic. Based on the circular letter of Bank Indonesia No.13/24/DPNP/2011, the Bank's Capital Adequacy Ratio (CAR) is $8 \%$, which means that if the bank has a CAR of more than $8 \%$, the bank is in the good and safe category because it has a high level of capital adequacy. good. So that in the context of the state of the country that is being engulfed by the COVID-19 pandemic, Indonesia's banking capital adequacy is still quite strong. Likewise, the position of the Capital Adequacy Ratio (CAR) at Indonesian regional development banks (BPD) in 2019 was on average $21.7 \%$.

Based on the background, the problem of this research is to test and analyze financial performance using bank-specific financial ratios. The ratios used include capital adequacy ratio (CAR), fixed assets to capital, non-performing productive assets, non-performing loans (NPL), return on equity (ROE), net interest margin (NIM), operating expenses to operating income (BOPO).), loan to deposit ratio (LDR)

\section{MATERIAL DAN METODE}

This study uses panel data of banking companies operating in the Eastern region of Indonesia from 2017 to 2020. There are 9 sample companies for 4 years of observation, so the total is 32 times the performance sample. The data is sourced from the 0JK data center, www.idx.co.id which is secondary. The data archives in this study are stored in documents including Financial Statements, Annual reports before the Covid period, and the Bank's performance in the period I-IV 2017-2020.

Inferential statistical data analysis includes correlation analysis between research variables, measuring and testing the suitability of the overall model (Goodness of Fit), evaluating variance (adjusted $R$ Squared), testing predictive relevance (Stone-Geiser), Testing effect size, testing influence between variables / significance ( $P$ value) and mediation test. Since all the variables in this study are manifest variables, there is no need to test the validity or reliability of the data.

\section{Table 1 Data Correlation Between Variables}

Korelasi ROE CAR BOPO NPL LDR




\begin{tabular}{|cccccc}
\hline CAR & 0.314 & 1 & & & \\
\hline BOPO & 0.227 & 0.169 & 1 & & \\
\hline NPL & 0.09 & 0.253 & 0.165 & 1 & \\
\hline LDR & -0.397 & -0.155 & -0.178 & -0.135 & 1 \\
\hline \multicolumn{5}{c}{ P. value } \\
\hline ROE & 1 & & \\
CAR & $<0.001$ & 1 & & & \\
\hline BOPO & 0.009 & 0.052 & 1 & & \\
\hline NPL & 0.005 & 0.003 & 0.057 & 1 & \\
\hline LDR & $<0.001$ & 0.075 & 0.04 & 0.022 & 1 \\
\hline
\end{tabular}

In the Table 1 , it can be seen that BOPO is positively correlated with CAR, with a correlation coefficient of 0.169 and significant is 0.052 . then positively correlated ROE with a correlation coefficient value of 0.314 and significant at $<0.001$. BOPO is also positively correlated with NPL and LDR but not significant. The CAR variable is positively correlated with the ROE variable. (Significance value at $<0.001$ ), CAR variable with (significance value at $<0.009$ ) and NPL variable with significance value at 0.040$)$.

\subsection{GOODNESS OF FIT TEST}

Goodness of fit testing is carried out to produce a research model that is in accordance with the original data. According to Latan and Ghozali (2016) the results of the evaluation of the suitability of this model will provide benefits for measuring the quality of the model. The results of the model suitability test / goodness of fit are presented in the following table.

\begin{tabular}{|c|c|c|c|}
\hline \multicolumn{4}{|l|}{ Table 2 Goodness of Fit } \\
\hline Criteria & Parameter & Rule of thumb & resume \\
\hline Average path coefficient (APC) & 0.177 & Acceptable $\mathrm{P}<0.05$ & accept \\
\hline \multicolumn{4}{|c|}{$\mathrm{P}<0.001$} \\
\hline Average R Squared (ARS) & 0.218 & Acceptable $\mathrm{P}<0.05$ & accept \\
\hline \multicolumn{4}{|c|}{$\mathrm{P}=0.025$} \\
\hline $\begin{array}{l}\text { Average adjusted R Squared } \\
\text { (AARS) }\end{array}$ & $\begin{array}{c}0.191 \\
P=0.047\end{array}$ & Acceptable $\mathrm{P}<0.05$ & accept \\
\hline Average block VIF (AVIF) & 1.132 & Acceptable if $\leq 5$ ideally $\leq 3.3$ & accept \\
\hline $\begin{array}{l}\text { Average Full Collinearity VIF } \\
\text { (AFVIF) }\end{array}$ & 1.175 & Acceptable if $\leq 5$ ideally $\leq 3.3$ & accept \\
\hline Tenenhaus GoF (GoF) & 0.467 & $\begin{array}{c}\text { Small } \geq 0.1 \text { Medium } \geq 0.25 \text { Large } \geq \\
0.36\end{array}$ & accept \\
\hline Sympson's paradox ratio (SPR) & 0.889 & Acceptable if $\geq 0.7$. ideally $=1$ & accept \\
\hline $\begin{array}{l}\text { R squared contribution ratio } \\
\text { (RSCR) }\end{array}$ & 0.982 & Acceptable if $\geq 0.9$. ideally $=1$ & accept \\
\hline $\begin{array}{l}\text { Statistical suppression ratio } \\
\text { (SSR) }\end{array}$ & 0.889 & Acceptable if $\geq 0.7$ & accept \\
\hline
\end{tabular}

output Warp PLS 5.0

The results of the goodness of fit model test in the table above can be explained this research model has a good and acceptable fit value, where the P-Value APC, ARS $<0.005$. Meanwhile, in testing the multicollinearity problem between exogenous 
variables, the AVIF value is 1.132 and the AFVIF value is 1.175 which 3.30 in this case means that there is no multicollinearity between exogenous variables. Furthermore, the size of the predictive power of the Tenenhaus GoF (GoF) model produces a value of $0.467(\geq 0.36)$ which means the predictive power of this model is very strong and acceptable. In measuring the causality problem in the research model with Sympson's paradox ratio (SPR), the resulting value of 0.889 ( $\geq 0.7$ ) is still acceptable because the ideal value is 1 . Furthermore, to find out that the research model is free from negative $\mathrm{R}$ squared contributions, it can be seen from the R squared value. contribution ratio (RSCR) which produces a value of 0.982 where 0.9 with an ideal value of 1 .

The next test is the problem of the impact of statistical suppression where a path coefficient has a large value when compared to the path correlation relationship that connects two variables. Testing the impact of statistical suppression problems resulted in a Statistical suppression ratio (SSR) value of 0.889 0.7. this means that the model is free from statistical suppression effect problems (Latan and Ghozali 2016). Looking at the results of the goodness of fit test, this research model has a good fit. These results indicate the suitability of the model with the support of available observational data.

\subsection{FULL COLLINEARITY VIF TEST}

Full Collinearity VIF test includes vertical and lateral multicollinearity. (Solihin and Ratmono). Vertical or classical collinearity is collinearity between predictor variables in the same block, while lateral collinearity is collinearity between predictor variables and criteria. Lateral collinearity was also used to test common methods bias. In the Full Collinearity VIF test, the criteria must be lower than 3.3 (Kock 2013). The adjusted R squared test is used to explain the effect of certain exogenous variables on endogenous variables whether they have a substantive effect (Latan and Ghozali 2016). Meanwhile, the Q-squared test is used to determine whether the model has predictive relevance or not (Latan and Ghozali 2016). The results of the Full Collinearity VIF, Adjusted R Squared and Q Squared tests are presented in the following Table 3.

\begin{tabular}{|c|ccccc|}
\hline \multicolumn{6}{|c|}{ Table 3 Full Collinearity VIF Test } \\
\hline & BOPO & NPL & LDR & CAR & ROE \\
\hline Full Coll. VIF & 1.184 & 1.085 & 1.08 & 1.149 & 1.333 \\
\hline R Squared & & & & 0.189 & 0.294 \\
\hline Adj. R Squared & & & 0.167 & 0.261 \\
\hline $\begin{array}{l}\text { Q Squared } \\
\text { result output Warp PLS 5.0 }\end{array}$ & & 0.196 & 0.29 \\
\hline
\end{tabular}

Furthermore, to see whether the model is free from problems of vertical, lateral collinearity and common method bias, it can be seen based on the results of the full collinearity VIF test in the table where the construct in this study is categorized as very good were based on the rule of thumbs is $<3.3$, which means the model is free from vertical collinearity problems, lateral and common method bias. To see the variations that affect CAR, it can be seen in the adjusted $\mathrm{R}$ squared value of 0.167 which means that the effect of variations in BOPO, NPL, LDR is $16.7 \%$, the remaining $83.3 \%$ is explained by other variables not included in this research model. If you look at the rule of thumb for evaluating the structural model in this study, it can be 
categorized as weak, where the adjusted R squared value of 0.167 is smaller than $(\leq$ 0.25 weak category).

The adjusted $\mathrm{R}$ squared value for variations in the effect of BOPO, NPL LDR on ROE of 0.261 or $26.1 \%$, the remaining $73.9 \%$ is explained by other variables not included in this research model. If you look at the rule of thumb for evaluating the structural model in this study, it can be categorized as moderate, where the adjusted $R$ squared value of 0.261 is greater than ( $>0.25$ moderate category).

As a reference for testing whether the CAR variable has predictive relevance, it can be seen in the table above that the value of Q squared is $0.196(>0)$ which means the model has predictive relevance which if you look at the rule of thumb evaluation of the structural model produced by the CAR variable is included in the moderate category where $\left(\mathrm{Q}^{2} \geq 0.15\right)$. While the value of $\mathrm{Q}$ squared generated by the ROE variable is equal to $(0.290>0)$ which means the model has predictive relevance. If you look at the rule of thumb evaluation of the structural model, the ROE variable is included in the moderate category where $\left(Q^{2} \geq 0.15\right)$.

\subsection{EFFECT SIZE AND VIF TEST}

The result of the output effect size is the absolute value of the individual contribution of each predictor variable on the R-Squared value of the criterion variable, the effect size shows the effect of the predictor variable in a practical point of view. Furthermore, the VIF test presents the results of vertical collinearity testing, namely between predictor variables, the value of VIF is presented for each criterion variable showing the level of collinearity or redundancy between predictor variables (Solihin and Ratmono). Furthermore, the results of the effect size and VIF test are presented in the table

\begin{tabular}{|ccc|}
\hline \multicolumn{3}{|c|}{ Table 4 Effect Size dan VIF Test } \\
\hline Path Description & Effect size & VIF \\
\hline BOPO $\rightarrow$ ROE & 0.092 & 1.128 \\
\hline NPL $\rightarrow$ ROE & 0.096 & 1.097 \\
\hline LDR $\rightarrow$ ROE & 0,010 & 1.108 \\
\hline CAR $\rightarrow$ ROE & 0.085 & 1.293 \\
\hline BOPO $\rightarrow$ CAR & 0.072 & 1.002 \\
\hline NPL $\rightarrow$ CAR & 0.054 & 1.002 \\
\hline LDR $\rightarrow$ CAR & 0,018 & 1 \\
\hline output Warp PLS 5.0 & & \\
\hline
\end{tabular}

\section{RESULTS AND DISCUSSIONS}

Based on the figure and table, it shows the path coefficient and $p$ value for each direct effect between variables that have a positive effect. The relationship between the BOPO variable and ROE shows a coefficient value, 0.218 which is significant at $0.002^{* * *}$, the relationship between the NPL variable and ROE shows a coefficient value, 0.182 which is significant at $0.046^{*}$, the LDR variable relationship to ROE shows a coefficient value, 0.048 which is not significant at 0.276 . The relationship between BOPO and CAR shows a coefficient value, 0.277 which is significant at $0.001^{* * *}$, the relationship between NPL and CAR shows a coefficient value, 0.289 which is significant at $0.009^{* * *}$, the relationship between LDR and CAR variables shows a coefficient value, 0.135 which is not significant at 0.232 . Meanwhile, the 
relationship between the CAR variable and ROE shows a coefficient value of 0.237 , which is significant at $0.015^{* *}$.

\begin{tabular}{|ccc|}
\hline \multicolumn{3}{c}{ Table 5 Result Significance Test Between Variables } \\
\hline Path Description & Path Coefficient & Sig. (p-value) \\
\hline BOPO $\rightarrow$ ROE & 0.218 & $0.002^{* *}$ \\
\hline NPL $\rightarrow$ ROE & 0.182 & $0.046^{* *}$ \\
\hline LDR $\rightarrow$ ROE & 0.048 & 0.276 \\
\hline CAR $\rightarrow$ ROE & 0.237 & $0.015^{* *}$ \\
BOPO $\rightarrow$ CAR & 0.277 & $<0.001^{* * *}$ \\
\hline NPL $\rightarrow$ CAR & 0.289 & $0.009^{* *}$ \\
\hline LDR $\rightarrow$ CAR & 0.135 & 0.232 \\
\hline
\end{tabular}

output Warp PLS 5.0

This study followed the procedure as in the formulation and stages of mediation testing proposed by (Hair 2013). Sobel (1986), Baron Kenny (1986), Preacher and Hayes (2004). Testing the indirect effect of BOPO, NPL, LDR on ROE through CAR as a mediator. The results of the indirect test (indirect effect) and the total effect can be presented in the figure and table

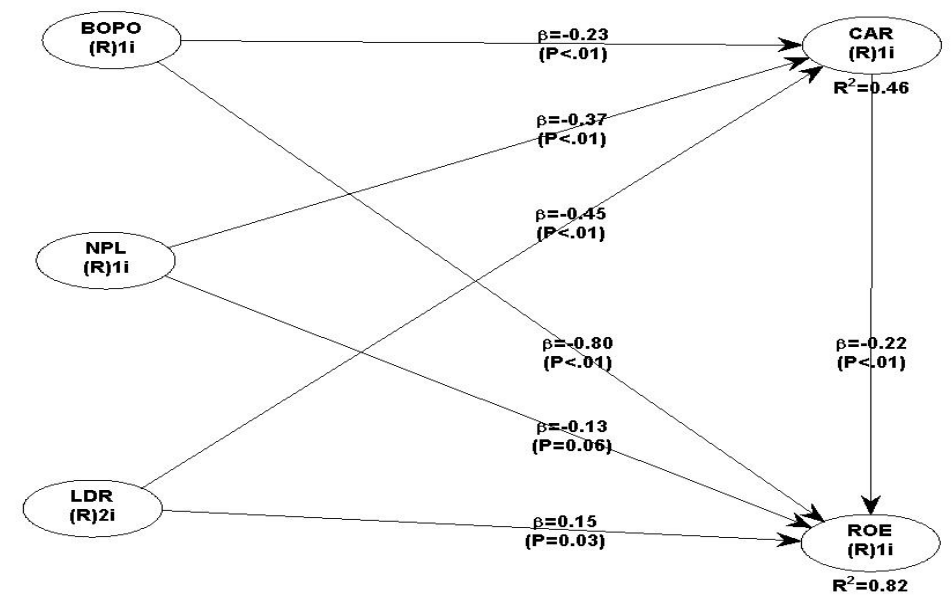

Figure 1 And Model Result WarpPLS 5.0

Based on the table presented on the mediation effect, the indirect effect coefficient for testing the BOPO $\rightarrow \mathrm{CAR} \rightarrow \mathrm{ROE}$ mediation hypothesis is 0.066 with a $\mathrm{p}$ value of $0.038(\mathrm{p}<5 \%) *$. These results explain that CAR is able to mediate the effect of BOPO on ROE. In testing the direct path relationship between BOPO and ROE, it is significant at $(0.002<1)^{* * *}$. While the direct relationship path of BOPO to CAR is significant at $(0.001<1 \%) * * *$. Similarly, the direct relationship path of CAR to ROE is $(0.002<1 \%){ }^{* * *}$ (Gudono 2016)

\begin{tabular}{|c|c|c|}
\hline Indirect effect & Path Coefficient & Sig. (P value) \\
\hline $\mathrm{BOPO} \rightarrow \mathrm{CAR} \rightarrow \mathrm{ROE}$ & 0.066 & $0.038^{*}$ \\
\hline $\mathrm{NPL} \rightarrow \mathrm{CAR} \rightarrow \mathrm{ROE}$ & 0.069 & $0.044^{*}$ \\
\hline LDR $\rightarrow$ CAR $\rightarrow$ ROE & 0.032 & 0.149 \\
\hline Total effect & Path Coefficient & Sig. (P value) \\
\hline
\end{tabular}




\begin{tabular}{rlc}
\hline BOPO $\rightarrow$ CAR $\rightarrow$ ROE & 0.284 & $<0.001$ \\
NPL $\rightarrow$ CAR $\rightarrow$ ROE & 0.250 & 0.005 \\
\hline LDR $\rightarrow$ CAR $\rightarrow$ ROE & 0.080 & 0.018 \\
\hline output Warp PLS 5.0 & & \\
\hline
\end{tabular}

output Warp PLS 5.0

\section{CONCLUSIONS AND RECOMMENDATIONS}

The empirical research model in this study is financial variables and ROE mediated by CAR, using PLS linear regression with the inner model of the warp3 algorithm, which tries to identify the relationship between latent variables that follow the $\mathrm{S}$ curve. WarpPls 5.0 was chosen because in this study it has a model that tested the mediating effect of three variables, namely BOPO, NPL, and LDR.

The results of WarpPls 5.0 can provide an explanation through the output of path coefficients either directly or indirectly. The results of the data processing show the path coefficient and $p$ value in each direct effect between variables that have a positive effect. The relationship between the BOPO variable and ROE shows a coefficient value, 0.218 which is significant at $0.002^{* * *}$, the relationship between the NPL variable and ROE shows a coefficient value, 0.182 which is significant at $0.046^{*}$, the LDR variable relationship to ROE shows a coefficient value, 0.048 which is not significant at 0.276 . The relationship between BOPO and CAR shows a coefficient value, 0.277 which is significant at $0.001^{* * *}$, the relationship between NPL and CAR shows a coefficient value, 0.289 which is significant at $0.009^{* * *}$, the relationship between LDR and CAR variables shows a coefficient value, 0.135 which is not significant at 0.232 . Meanwhile, the relationship between the CAR variable and ROE shows a coefficient value of 0.237 , which is significant at $0.015^{* *}$.

The results of the mediation effect test in the indirect effect coefficient table for testing the BOPO $\rightarrow \mathrm{CAR} \rightarrow \mathrm{ROE}$ mediation hypothesis is 0.066 with a p-value of 0.038 $(\mathrm{p}<5 \%)^{*}$. These results explain that CAR is able to mediate the effect of BOPO on ROE. In testing the direct path relationship between BOPO and ROE, it is significant at $(0.002<1)^{* * *}$. While the direct relationship path of BOPO to CAR is significant at $(0.001<1 \%)^{* * *}$. Likewise, the path of the direct relationship between CAR and ROE is $(0.002<1 \%) * * *$ (Gudono 2016).

\section{REFERENCES}

Arifin, Zaenal (2007). Teori keuangan dan pasar Modal. Yogyakarta : Ekonesia Kampus Fakultas Ekonomi UII.

Brigham, Eugene F, dan Michael C Ehrhardt (2011). Financial Management : Theory and Practice Vol. 13a, e : Shouth Westren.

Brigham, Eugene F., dan Joel F. Houston (2009). Fundamentals of Financial Management, 12th edition. Vol. 12. South-Western Cengage Learning 5191 Natorp Boulevard Mason, OH 45040 USA : South-Western, a part of Cengage Learning.

Chen, Su-Jane, et al. (2017). "Financial performance of Chinese airlines : Does state ownership matter ?" Journal of Hospitality and Tourism Management no. 33 :1-10. Retrieved from https://doi.org/10.1016/j.jhtm.2017.08.001

Dyson, John R (2010). "Accounting_for_Non-Accounting_Students." In, edited by 8th. England: Pearson Education Limited Edinburgh Gate Harlow Essex CM20 2JE England. 
Hartono, Jogiyanto (2008). Teori Portofolio dan analisis investasi. cetakan kelima vols. Jogyakarta : BPFE fakultas ekonomika dan Bisnis UGM.

Horne, James C. Van, dan Jr. John M. Wachowicz (2009). Fundamentals of Financial Management. Vol. 13e. England: Pearson Education Limited Edinburgh Gate Harlow Essex CM20 2JE England and associated Companies throughout the world.

Ikhwa, Nuzul (2006). "Analisis ROA dan ROE Terhadap Profitabilitas Bank Di Bursa Efek Indonesia." Al Masraf : Jurnal Lembaga Keuangan dan Perbankan no. 1 (2).

Sudana, I Made (2015). Teori dan Praktik Manajemen Keuangan Perusahaan, 2. Jakarta Erlangga

Zvi, Bodie, et al. (2008). Investment. Vol. Seventh Edition : McGraw-Hill International Edition 